\title{
MODIFIKASI PATI SECARA ASETILASI DAN APLIKASINYA PADA PEMBENTUKAN FILM
}

Nurhayati ${ }^{*}$

1Progran Studi Teknologi Hasil Pertanian, Fakultas Pertanian, Universitas Muhammadiyah Mataram ,nurhayati.faperta@ummat.ac.id

\section{INFO ARTIKEL}

\section{RiwayatArtikel:}

Diterima: 01-07-2019

Disetujui: 11-08-2019

\section{Kata Kunci:}

Modifikasi pati Asetilasi

Aplikasi film

\begin{abstract}
ABSTRAK
Abstrak: Seiring dengan perkembangan teknologi dan metode pengolahan yang dipergunakan, pati alami dapat dimodifikasi dengan tujuan untuk memperbaiki karakteristik fisiko kimianya, sehingga dapat dimanfaatkan untuk produk lanjut. Pati termodifikasi adalah pati yang gugus hidroksilnya telah diubah lewat suatu reaksi kimia (esterifikasi, eterifikasi atau oksidasi) atau dengan menggangu struktur asalnya. Salah satu metode modifikasi kimia pati yang umum digunakan adalah metode asetilasi yang menghasilkan pati asetat. Pati asetat merupakan hasil asetilasi pati dimana granula pati diesterkan dengan grup asetat dengan mensubstitusi gugus hidroksil pati. Pati termodifikasi secara asetilasi adalah salah satu modifikasi kimia dengan menyisipkan gugus asetil pada gugus $\mathrm{OH}$ pada pati melalui reaksi asetilasi. Reagen yang biasa digunakan pada metode asetilasi adalah vinil asetat, asam asetat, dan asetat anhidrat. Keunggulan sifat fisikokimia yang dimiliki oleh pati terasetilasi seperti suhu gelatinisasi, swelling power, solubility, dan tingkat kejernihan pasta (paste clarity) yang tinggi, serta memiliki stabilitas penyimpanan dan pemasakan yang lebih baik jika dibandingkan dengan pati asalnya. Selain itu, kualitas produk yang dihasilkan dari pati terasetilasi lebih stabil dan tahan terhadap retrogradasi. Secara umum modifikasi pati secara asetilasi sangat dipengaruhi oleh beberapa faktor diantaranya faktor intrinsik dan ekstrinsik. Faktor intrinsik yang meliputi struktur granula (bentuk dan ukuran granula), komposisi granula (Rasio Amilopektin dan Amilosa serta komposisi selain pati) sedangkan faktor ekstrinsik terdiri dari reagents (Jenis Reagen, Konsentrasi), kondisi media reaksi (suhu, $\mathrm{pH}$, lama reaksi dan tekanan). Faktor - faktor tersebut akan berpengaruh terhadap derajat substitusi, \% asetil, sifat - sifat fisiko kimia, morfologi dan reologi, termal serta pasting pati terasetilasi. Dalam aplikasinya berdasarkan tingkat derajat substitusi, pati asetat diklasifikasikan menjadi tiga tingkat yakni rendah, menengah, tinggi. Pati asetat dengan DS rendah $(0,01-0,2)$ dapat berfungsi sebagai pembentuk film, pengikat, pelekat, penebal, penstabil, dan agen texturing.
\end{abstract}

Abstract: Along with the development of technology and processing methods used, native starch can be modified to improve its chemical, physicochemical characteristics so that it can be utilized for further products. Modified starches are starches whose hydroxyl groups have been changed by a chemical reaction (esterification, etherification, or oxidation) or by disturbing the original structure. One method of chemical starch modification commonly used is acetylation, which produces acetylated starch. Acetylated starches are produced from starch granules ethered with acetate groups by substituting starch hydroxyl groups. Chemical starch modification by acetylation with inserting an acetyl group in the $\mathrm{OH}$ group starch through the acetylation reaction. The reagents commonly used in the acetylation method are vinyl acetate, acetic acid, and acetic anhydrous. Acetylated starch has the physicochemical properties advantages such as gelatinization temperature, development power, solubility, and paste clarity are high. Another advantage is better storage and cooking stability when compared to native starch. In addition, the quality of the products produced from starch acetate is more stable and resistant to retrogradation. In general, starch modification by acetylation is greatly influenced by several factors, including intrinsic and extrinsic factors. Intrinsic factors include the structure of the granules (the shape and size of the granules), the composition of the granules (ratio of amylopectin and amylose, and compositions other than starch). While extrinsic factors consist 
Jurnal AGROTEK Vol. 6 No.2, Agustus 2019./modifikasi pati secara asetilasi dan aplikasinya pada pembentukan film/ Nurhayati

of reagents (reagent type, concentration), condition of the media reaction (temperature, $\mathrm{pH}$, reaction time, and pressure ), these factors will affect the degree of substitution,\% acetyl, physicochemical, morphological and rheological properties, thermal and pasting of acetylated starch. In its application based on the degree of substitution, acetylated starch is classified into three levels, namely low, medium, high. Acetate starch with low DS (0.01-0.2) can function as film-forming, binder, adhesive, thickener, stabilizer, and texturing agent.

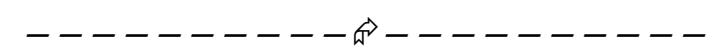




\section{A. PENDAhUluan}

Pati adalah salah satu penyusun utama bahan pangan yang paling banyak dan luas terdapat di alam. Sebagian besar pati di simpan dalam umbi (ubi kayu, ubi jalar, kentang), biji (jagung, padi, gandum), batang (sagu) dan buah. Disamping itu pati merupakan zat gizi penting dalam kehidupan sehari-hari, dimana dalam tubuh manusia kebutuhan energi hampir $80 \%$ dipenuhi dari karbohidrat.

Pati merupakan karbohidrat yang banyak dijumpai pada tanaman yang banyak dimanfaatkan untuk produk pangan. Seiring dengan perkembangan teknologi dan metode pengolahan yang dipergunakan, pati alami dapat dimodifikasi dengan tujuan untuk memperbaiki karakteristik fisiko kimianya, sehingga dapat dimanfaatkan untuk produk lanjut. Pati termodifikasi adalah pati yang gugus hidroksilnya telah diubah lewat suatu reaksi kimia (esterifikasi, sterifikasi atau oksidasi) atau dengan menggangu struktur asalnya. Sedangkan menurut [1] pati diberi perlakuan tertentu dengan tujuan untuk menghasilkn sifat yang lebih baik untuk memperbaiki sifat sebelumnya atau untuk merubah beberapa sifat sebelumnya atau untuk merubah beberapa sifat lainnya. Perlakuan ini dapat mencakup penggunaan panas, asam, alkali, zat pengoksidasi atau bahan kimia lainnya yang akan menghasilkan gugus kimia baru dan atau perubahan bentuk, ukuran serta struktur molekul pati.

Teknologi modifikasi pati dapat dilakukan baik secara genetik, enzimatis, fisika, kimia maupun kombinasi keduanya. Modifikasi pati secara enzimatis dilakukan dengan enzim - enzim, sedangkan secara fisik melalui beberapa cara, diantaranya yaitu pengeringan, ekstrusi, pengeringan dengan spray, pemanasan, pendinginan, pemasakan maupun perlakuan fisik lainnya. Selain itu, proses modifikasi pati juga dapat dilakukan secara kimia dengan cara cross linking, substitusi maupun kombinasi keduanya dengan menggunakan bahan kimia sebagai bahan pembantu reaksi selama proses pengolahan.

Salah satu metode modifikasi kimia pati yang umum digunakan adalah metode asetilasi yang menghasilkan pati asetat. Pati asetat merupakan hasil asetilasi pati dimana granula pati diesterkan dengan grup asetat dengan mensubstitusi gugus hidroksil pati. untuk memproduksi pati termodifikasi sacara asetilasi, perlu diperhatikan dari aspek penggunaan bahan dan metode.

\section{B. PEMBAHASAN}

\section{Definisi}

Pati termodifikasi secara asetilasi adalah salah satu modifikasi kimia dengan menyisipkan gugus asetil pada gugus $\mathrm{OH}$ pada pati melalui reaksi asetilasi. Reagen yang biasa digunakan pada metode asetilasi adalah vinil asetat, asam asetat, dan asetat anhidrat. Asetilasi dapat dilakukan dengan mereaksikan suspensi pati encer dengan asetat anhidrida dalam kondisi alkali (pH 8,0-8,4) dan suhu $25^{\circ} \mathrm{C}$, kondisi alkalinitas dicapai dengan menggunakan $\mathrm{NaOH} 3 \%$ [2].

\section{Mekanisme Reaksi Asetilasi}

Mekanisme pembentukan pati ester asetat yang dikatalisis dengan asam sulfat ditunjukkan pada Gambar 1. Dari gambar 1 terlihat bahwa asam asetat bereaksi dengan gugus hidroksil pada pati dimana asam sulfat yang menyediakan ion $\mathrm{H}+$ memprotonasi gugus karbonil pada asam asetat sehingga gugus hidroksil dari pati lebih mudah menyerang atom $\mathrm{C}$ pada gugus karbonil asam asetat. Sehingga diperoleh struktur intermediet ester pati asetat, intermediet ini kemudian melepaskan ion $\mathrm{H}^{+}$dan molekul air, sehingga terbentuk ester pati asetat.

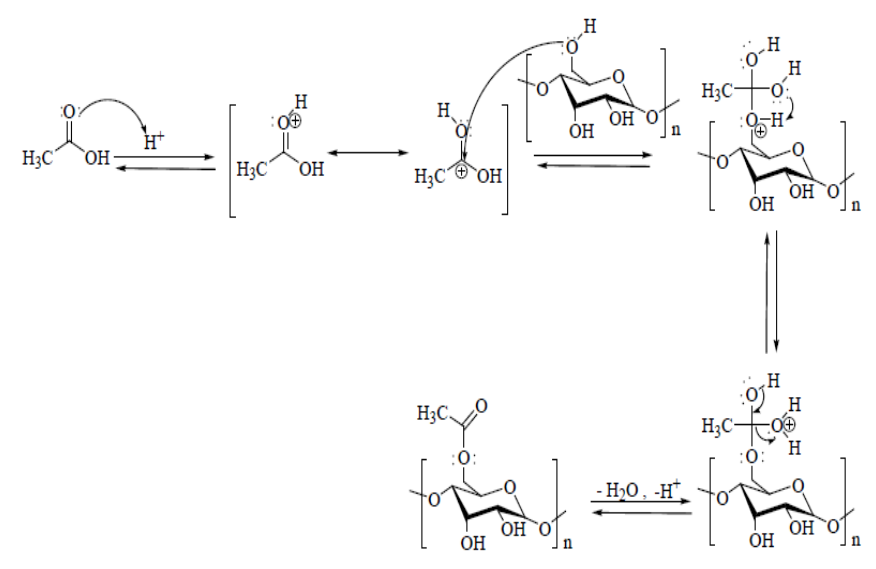

Gambar 1. Mekanisme pembentukan ester pati asetat dikatalisis dengan asam sulfat [3].

\section{Keunggulan Pati Terasetilasi dengan Pati Alami}

Pati alami umumnya memiliki kelemahan yang mengurangi aplikasinya di dalam proses pengolahan pangan, beberapa di antaranya adalah kemampuan membentuk gel yang tidak konsisten, menghasilkan suspensi pati yang tidak tahan dengan suhu tinggi, pada suhu dingin mudah mengalami sineresis akibat terjadinya retrogradasi pati, kemampuan gelatinisasi yang rendah pada kondisi asam sehingga mudah mengalami hidrolisis, rendahnya tingkat viskositas karna tidak tahan proses mekanis seperti proses pengadukan atau pemompaan. Sedangkan keunggulan sifat fisikokimia yang dimiliki oleh pati terasetilasi seperti suhu gelatinisasi, swelling power, solubility, dan tingkat kejernihan pasta (paste clarity) yang tinggi, serta memiliki stabilitas penyimpanan dan pemasakan yang lebih baik jika dibandingkan dengan pati asalnya. Selain itu, kualitas produk yang dihasilkan dari pati terasetilasi lebih stabil dan tahan terhadap retrogradasi.

4. Faktor-Faktor yang Mempengaruhi Modifikasi pati terasetilasi dan Pengaruhnya terhadap Derajat Substitusi, Sifat Fisikokimia, Morfologi, Termal dan Pasting

Proses asetilasi ditujukan untuk mendapatkan pati asetat yang dipengaruhi oleh jenis katalis, konsentrasi pereaksi, suhu dan lama waktu reaksi asetilasi [4;5]. Menurut [6] menyebutkan bahwa secara umum modifikasi pati secara asetilasi sangat dipengaruhi oleh beberapa faktor diantaranya faktor intrinsik dan ekstrinsik. Faktor intrinsik yang meliputi struktur granula (bentuk dan ukuran granula), komposisi granula (Rasio Amilopektin dan Amilosa serta komposisi selain pati) sedangkan faktor ekstrinsik terdiri dari reagents (Jenis Reagen, Konsentrasi), kondisi media reaksi (suhu, pH, lama reaksi dan tekanan). Faktor - faktor tersebut akan berpengaruh terhadap derajat substitusi, \% asetil, sifat - sifat fisiko 
kimia, morfologi dan reologi, termal serta pasting pati terasetilasi.

\section{a. Derajat Substitusi}

Derajat substitusi (DS) dan (\%) asetil digunakan untuk mengetahui berapa banyak gugus asetil yang tersubsitusi ke dalam pati yang terasetilasi. DS merupakan parameter yang menentukan penggunaan pati terasetilasi secara komersial, dan menentukan besarnya perubahan sifat fungsional pati asetat dari pati alaminya.

Derajat substitusi (DS) sangat dipengaruhi oleh sumber tanaman, pati alami dari berbagai jenis sumber tanaman mempunyai keunikan tersendiri. Struktur dan jenis material antara tiap sumber pati berbeda tergantung sifat-sifat botani sumber pati tersebut. Pati tersusun paling sedikit oleh tiga komponen utama yaitu amilosa, amilopektin dan material antara seperti, protein dan lemak Umumnya pati mengandung 15-30\% amilosa 70-85\% amilopektin dan 5-10\% material antara. Pada satu jenis tanaman dengan varietas yang berbeda - beda komposisi materialnya bervariasi seperti yang disajikan pada Tabel 1.

Tabel 1. Karakteristik Komposisi Pati Barley yang diisolasi dari varietas yang berbeda

\begin{tabular}{|c|c|c|c|c|c|}
\hline Varietas & Pati (\%) & $\begin{array}{l}\text { Lemak } \\
(\%)\end{array}$ & $\begin{array}{l}\text { Protein } \\
(\%)\end{array}$ & $\begin{array}{l}\text { Amilosa } \\
(\%)\end{array}$ & $\begin{array}{l}\text { Amilopekti } \\
\mathrm{n}(\%)\end{array}$ \\
\hline $\begin{array}{l}\text { Zangqing } \\
8\end{array}$ & $\begin{array}{l}95,14 \pm 2 \\
20 b\end{array}$ & $\begin{array}{l}0,02 \pm 0, \\
01 \mathrm{a}\end{array}$ & $\begin{array}{l}0,42 \pm 0 \\
07 a\end{array}$ & $\begin{array}{l}23,85 \pm 2 \\
05 b c\end{array}$ & $\begin{array}{l}71,30 \pm 2,05 \\
\mathrm{a}\end{array}$ \\
\hline $\begin{array}{l}\text { Zangqing } \\
148\end{array}$ & $\begin{array}{l}90,58 \pm 2 \\
, 59 c\end{array}$ & $\begin{array}{l}0,02 \pm 0, \\
00 \mathrm{ab}\end{array}$ & $\begin{array}{l}0,44 \pm 0, \\
02 \mathrm{a}\end{array}$ & $\begin{array}{l}24,75 \pm 1 \\
16 \text { abc }\end{array}$ & $\begin{array}{l}65,89 \pm 1,63 \\
b\end{array}$ \\
\hline Beiqing 6 & $\begin{array}{l}97,95 \pm 1 \\
34 a\end{array}$ & $\begin{array}{l}0,01 \pm 0, \\
01 \mathrm{~b}\end{array}$ & $\begin{array}{l}0,31 \pm 0, \\
05 \text { a }\end{array}$ & $\begin{array}{l}27,49 \pm 0 \\
55 a\end{array}$ & $\begin{array}{l}70,46 \pm 0,55 \\
\mathrm{a}\end{array}$ \\
\hline $\begin{array}{l}\text { Zangqing } \\
25\end{array}$ & $\begin{array}{l}97,18 \pm 0 \\
, 80 \mathrm{ab}\end{array}$ & $\begin{array}{l}0,01 \pm 0, \\
00 \mathrm{ab}\end{array}$ & $\begin{array}{l}0,33 \pm 0, \\
04 \mathrm{a}\end{array}$ & $\begin{array}{l}27,12 \pm 0 \\
33 \mathrm{ab}\end{array}$ & $\begin{array}{l}70,06 \pm 0,33 \\
\text { a }\end{array}$ \\
\hline Kunlun12 & $\begin{array}{l}95,57 \pm 0 \\
, 56 \mathrm{ab}\end{array}$ & $\begin{array}{l}0,01 \pm 0, \\
01 \mathrm{ab}\end{array}$ & $\begin{array}{l}0,45 \pm 0, \\
03 \mathrm{a}\end{array}$ & $\begin{array}{l}24,97 \pm 0 \\
17 \text { abc }\end{array}$ & $\begin{array}{l}70,60 \pm 0,17 \\
\mathrm{a}\end{array}$ \\
\hline $\begin{array}{l}\text { Zangqing } \\
320\end{array}$ & $\begin{array}{l}96,96 \pm 0 \\
, 84 a b\end{array}$ & $\begin{array}{l}0,01 \pm 0, \\
00 \mathrm{ab}\end{array}$ & $\begin{array}{l}0,39 \pm 0, \\
05 \mathrm{a}\end{array}$ & $\begin{array}{l}26,23 \pm 2 \\
96 \text { abc }\end{array}$ & $\begin{array}{l}70,73 \pm 2,96 \\
\text { a }\end{array}$ \\
\hline Xila19 & $\begin{array}{l}95,36 \pm 0 \\
18 a b\end{array}$ & $\begin{array}{l}0,01 \pm 0, \\
00 \mathrm{ab}\end{array}$ & $\begin{array}{l}0,32 \pm 0 \\
09 \text { a }\end{array}$ & $\begin{array}{l}22,72 \pm 0 \\
85 c\end{array}$ & $\begin{array}{l}72,64 \pm 0,85 \\
\text { a }\end{array}$ \\
\hline
\end{tabular}

Sumber : [7]

Kandungan amilosa yang berbeda - beda pada satu tanaman dengan varietas yang berbeda - beda pun akan mempengaruhi \% asetil dan nilai DS seperti yang disajikan pada Tabel 2 .

Tabel 2. \% Asetil dan DS pati beras terasetilasi dari kultivar yang berbeda

\begin{tabular}{lll}
\hline Kultivar & $\%$ Asetil & DS \\
\hline PR-106 & $2,77^{\mathrm{b}}$ & $0,107^{\mathrm{b}}$ \\
PR-114 & $2,46^{\mathrm{a}}$ & $0,095^{\mathrm{a}}$ \\
IR-8 & $3,03^{\mathrm{b}}$ & $0,118^{\mathrm{b}}$ \\
PR-103 & $2,26^{\mathrm{a}}$ & $0,087^{\mathrm{a}}$ \\
PR-113 & $3,68^{\mathrm{c}}$ & $0,144^{\mathrm{c}}$ \\
\hline DS = derajat substitusi $;$ Huruf yang sama di dalam kolom \\
menunjukkan tidak berbeda nyata $(\rho<0,05)$ \\
Sumber : [8]
\end{tabular}

Pada Tabel 2 terlihat bahwa (\%) asetil dan DS pati asetat masing-masing untuk kultivar yang berbeda bervariasi antara 2,26-3,68\% dan 0,087-0,144. Kultivar PR-113 menunjukkan (\%) asetil dan DS tertinggi sedangkan untuk DS PR-103menunjukkan nilai terendah.

Variasi derajat substitusi antara pati yang berbeda mungkin juga karena perbedaan dalam kemasan intragranula pati beras. Karena rantai amilosa yang dikemas dalam daerah amorf serta tata letak rantai amilosa dan amilopektin dapat mempengaruhi substitusi reaksi kimia dalam unit glukosa makromolekul pati [9].
Granula pati beras dilaporkan lebih kaku dibandingkan pati kentang dan jagung [10].

Selain itu (\%) asetil dan DS yang diamati lebih rendah dibandingkan dengan penelitian yang dilakukan sebelumnya pada kentang dan jagung pati dengan reagen asetat anhydride pada kondisi yang sama [2]. Hal ini kemungkinan besar disebabkan oleh perbedaan dalam kandungan amilosa dan struktur granular beras, kentang dan pati jagung.

[11] mengamati pengaruh asetilasi terhadap sifat fisikokimia, morfologi, pati beras yang mengandung highmedium-low amilosa seperti yang disajikan pada Tabel 3.

Tabel 3. Persentase asetil dan derajat substitusi pada pati beras yang mengandung high-medium-low amilosa dengan lama reaksi yang berbeda

\begin{tabular}{lcccccc}
\hline Pati & \multicolumn{2}{c}{10} & \multicolumn{2}{c}{30} & \multicolumn{2}{c}{90} \\
& $\begin{array}{c}\text { Asetil } \\
(\%)\end{array}$ & DS & $\begin{array}{c}\text { Asetil } \\
(\%)\end{array}$ & DS & $\begin{array}{c}\text { Asetil } \\
(\%)\end{array}$ & DS \\
\hline $\begin{array}{l}\text { High - } \\
\text { amylose }\end{array}$ & $6,17^{\mathrm{c}}$ & $0,24^{\mathrm{c}}$ & $10,22^{\mathrm{c}}$ & $0,42^{\mathrm{c}}$ & $16,10^{\mathrm{c}}$ & $0,72^{\mathrm{c}}$ \\
$\begin{array}{l}\text { Medium - } \\
\text { amylase }\end{array}$ & $9,23^{\mathrm{b}}$ & $0,38^{\mathrm{b}}$ & $10,75^{\mathrm{b}}$ & $0,45^{\mathrm{b}}$ & $17,80^{\mathrm{b}}$ & $0,81^{\mathrm{b}}$ \\
Low - & $10,34^{\mathrm{a}}$ & $0,43^{\mathrm{a}}$ & $11,60^{\mathrm{a}}$ & $0,49^{\mathrm{a}}$ & $20,47^{\mathrm{a}}$ & $0,96^{\mathrm{a}}$ \\
\hline
\end{tabular}

amylose

Hasil merupakan rata-rata dari tiga perlakuan. Huruf yang berbeda pada kolom yang sama menunjukkan perbedaan secara statistic $(\rho<0,05)$.

Sumber : [11]

Asetilasi pati menghasilkan pati beras dengan nilai DS $0,34 \pm 0$ yang berbeda tergantung pada kandungan amilosa dan lama reaksi (Tabel 3). Pati beras terasetilasi dengan lama 0,38 $\pm 0,03 a$ reaksi 90 menit menunjukkan nilai DS dan \%Ac yang lebih $0,39 \pm 0$ teikggi dibandingkan lama reaksi 10 dan 30 menit. Hal ini ${ }_{ \pm 0}$ disebabkan karena kemampuan kelompok asetil untuk menyisip pada pati beras dengan kandungan low-amilosa $0,35 \pm 0,093$ ih besar bandingkan pada medium dan high-amilosa $0,37 \pm 0$,pati. Hal yang senada juga dilaporkan oleh [12] yang mempelajari karakteristik asetilasi pada pati jagung yang high-amilosa, normal, dan waxy. Dimana kemudahan penyisipan kelompok asetil pada waxy dibandingkan yang high- amilosa. Selain itu, semakin lama waktu asetilasi, \% Ac dan DS semakin meningkat. Hal ini disebabkan karena semakin lama waktu kontak antara asam asetat dengan pati maka lama-kelamaan gugus asetil pada asam asetat akan melemahkan ikatan hidrogen pada pati tersebut yang menyebabkan semakin banyak gugus $\mathrm{OH}$ - pati yang tersubstitusi oleh gugus asetil.

Selain pengaruh kandungan amilosa, reagen dan katalisator yang digunakan juga mempengaruhi nilai DS, seperti penelitian yang dilakukan oleh [13] yang mempelajari pengaruh rasio asam asetat dan asetat anhidydride terhadap sifat pati jagung yang diperlakukan menggunakan iodium sebagai katalisator dengan bantuan microwave ditunjukkan pada Tabel 4.

Tabel 4. Pengaruh Rasio Asam asetat dan asetat anhidride terhadap nilai DS pati jagung sebelum dan sesudah asetilasi

\begin{tabular}{llllllll}
\hline $\begin{array}{l}\text { Samp } \\
\text { el }\end{array}$ & $\begin{array}{c}\text { Asam } \\
\text { asetat } \\
(\mathrm{mmol})\end{array}$ & $\begin{array}{c}\text { Asetat } \\
\text { anhidri } \\
\text { da } \\
(\mathrm{mmol})\end{array}$ & $\begin{array}{c}\text { Rasio } \\
(\mathrm{a})\end{array}$ & $\begin{array}{c}\mathrm{I}_{2} \\
(\mathrm{mmol})\end{array}$ & $\begin{array}{c}\text { Lama } \\
(\text { menit })\end{array}$ & $\begin{array}{c}\text { Suhu } \\
\left({ }^{\circ} \mathrm{C}\right)\end{array}$ & DS \\
\hline Nativ & - & - & - & - & - & - & - \\
$e$ & & & & & & & \\
$\mathrm{SA}_{0}$ & 90 & 90 & $1: 1$ & 0 & 2 & 100 & 0,25 \\
$\mathrm{SA}_{1}$ & 120 & 60 & $2: 1$ & 1,75 & 2 & 100 & 2,656 \\
$\mathrm{SA}_{2}$ & 90 & 90 & $1: 1$ & 1,75 & 2 & 100 & 2,934
\end{tabular}




\begin{tabular}{llllllll}
$\mathrm{SA}_{3}$ & 60 & 120 & $1: 2$ & 1,75 & 2 & 100 & 2,656 \\
$\mathrm{SA}_{4}$ & 30 & 150 & $1: 5$ & 1,75 & 2 & 100 & 2,029 \\
$\mathrm{SA}_{5}$ & 0 & 180 & $0: 1$ & 1,75 & 2 & 100 & 1,837 \\
\multicolumn{7}{r}{ a rasio Asam asetat: Asetat anhidrida $(\mathrm{mol} / \mathrm{mol})$}
\end{tabular}

Sumber : [13]

Dari Tabel 4 terlihat bahwa nilai DS tertinggi adalah 2,93 dengan perlakuan rasio asam asetat dan asetat anhidride yang sama dengan pemberian katalisator iodine. Adapun yang tanpa perlakuan katalisator menunjukkan nilai yang terendah yakni 0,25 . Hal ini disebabkan karena iodine bertindak sebagai Lewis acid catalyst. Rasio reagen yang berbeda-beda juga menunjukkan dampak yang nilai DS yang berbeda - beda.

Dalam hal ini, reaksi pretreatment dengan asam asetat dapat mereaktifkan bagian-bagian dari molekul pati, yang kemudian esterifikasi dipercepat dengan anhidrida asetat sehingga efektif meningkatkan DS seperti yang diungkapkan oleh [1] bahwa sejumlah besar asetat anhidrida diperlukan untuk merangsang collision molekul pati dalam reaksi. selain pemberian reagen dan katalisator, beberapa metode seperti penggunaan UHP (Ultra High Pressure) juga dapat mempengaruhi nilai derajat substitusi. [14] mempelajari pengaruh UHP terhadap karakteristik pati jagung terasetilasi yang ditunjukkan pada Tabel 5.

Tabel 5 Sistem reaksi dan nilai derajat substitusi (a) granula pati jagung terasetilasi menggunakan asetat anhidrida.

\begin{tabular}{lllllll}
\hline Perlakuan & $\begin{array}{l}\text { Regen } \\
(\mathrm{s.b})\end{array}$ & $\mathrm{pH}$ & $\begin{array}{l}\text { Tekanan } \\
(\mathrm{MPa})\end{array}$ & $\begin{array}{l}\text { Suhu } \\
\left({ }^{\circ} \mathrm{C}\right)\end{array}$ & $\begin{array}{l}\text { Lama } \\
(\mathrm{menit})\end{array}$ & $\mathrm{DS}$ \\
\hline $\begin{array}{l}\text { Kontrol } \\
\text { reaksi }\end{array}$ & 12,0 & $8,0-8,5$ & - & 30 & 60 & $0,089 \pm 0,002^{\mathrm{A}}$ \\
UHP1 & 12,0 & $8,0-8,5$ & 0,1 & 25 & 15 & $0,047 \pm 0,000^{\mathrm{D}}$ \\
UHP2 & 12,0 & $8,0-8,5$ & 100 & 25 & 15 & $0,046 \pm 0,002^{\mathrm{D}}$ \\
UHP3 & 12,0 & $8,0-8,5$ & 200 & 25 & 15 & $0,048 \pm 0,001^{\mathrm{D}}$ \\
UHP4 & 12,0 & $8,0-8,5$ & 300 & 25 & 15 & $0,055 \pm 0,000^{\mathrm{C}}$ \\
UHP5 & 12,0 & $8,0-8,5$ & 400 & 25 & 15 & $0,067 \pm 0,002^{\mathrm{B}}$ \\
\hline
\end{tabular}

aRerata nilai dari dua ulangan reaksi; nilai didalam kolom menunjukkan

perbedaan yang nyata $(\rho<0,05)$

bs.b, basis berat kering pati

Sumber : [14]

Sintesis pati jagung terasetilasi dengan tanpa

(kontrol) dan adanya pemberian tekanan (UHP) memberikan perbedaan nilai DS. Pada Tabel 5 menunjukkan bahwa nilai DS yang lebih rendah dengan pemberian tekanan, hal ini kemungkinan besar disebabkan perbedaan lama reaksi antara konvensional dan UHP. [1] melaporkan bahwa nilai DS pati asetat seiring dengan bertambahnya waktu reaksi yang berkisar antara 30-240 menit. Meskipun demikian, adanya bantuan UHP memberikan waktu reaksi 75\% lebih singkat dibandingkan dengan kontrol, selain itu penggunaan suhu yang lebih rendah sehingga dapat mengurangi energi yang digunakan.

\section{b. Sifat Fisikokimia Pati Terasetilasi}

Sifat fisikokimia yang meliputi swelling power dan solubility. Swelling power merupakan kenaikan volume dan berat maksimum pati selama mengalami pengembangan di dalam air. Swelling power menunjukkan kemampuan pati untuk mengembang dalam air. Swelling power yang tinggi berarti semakin tinggi pula kemampuan pati mengembang dalam air. Nilai swelling power perlu diketahui untuk memperkirakan ukuran atau volume wadah yang digunakan dalam proses produksi sehingga jika pati mengalami swelling, wadah yang digunakan masih bisa menampung pati tersebut. Semakin besar sweeling power berarti semakin banyak air yang diserap selama pemasakan. Adapun untuk pola solubility pati dapat diketahui dengan cara mengukur berat supernatan yang telah dikeringkan dari hasil pengukuran swelling power. Solubility terkait dengan kemudahan molekul air untuk berinterkasi dengan molekul dalam granula pati dan menggantikan interaksi hidrogen antar molekul sehingga granula akan lebih mudah menyerap air dan mempunyai pengembangan yang tinggi. Adanya pengembangan tersebut akan menekan granula dari dalam sehingga granula akan pecah dan molekul pati terutama amilosa akan keluar. Sifat swelling dan solubility pada pati sangat tergantung pada kekuatan dan sifat alami antar molekul di dalam granula pati, yang juga tergantung pada sifat alami dan kekuatan daya ikat granula. Salah satu faktor yang menentukan daya ikat tersebut perbandingan amilosa dan amilopektin. Selain itu lama proses reaksi asetilasi juga mempengaruhi sifat sweeling power dan solubility karna berkaitan dengan lamanya kontak gugus asetil dengan molekul pati. Seperti penelitian yang dilakukan oleh [11] yang mempelajari pengaruh low-medium-high amilosa pati beras terasetilasi terhadap sweeling power dan solubility yang ditunjukkan pada Tabel 6 .

Tabel 6. Pengaruh kandungan amilosa dan lama reaksi terhadap swelling power dan solubility pada lowmedium-high amilosa pati beras sebelum dan sesudah asetilasi.

\begin{tabular}{lllll}
\hline Sifat & $\begin{array}{l}\text { Lama } \\
\text { reaksi }\end{array}$ & High amylose & $\begin{array}{l}\text { Medium } \\
\text { amylose }\end{array}$ & $\begin{array}{l}\text { low } \\
\text { amylose }\end{array}$ \\
\hline $\begin{array}{l}\text { Swelling } \\
\text { power(g/g) }\end{array}$ & Native & $17,84 \mathrm{aB}$ & $22,18 \mathrm{aA}$ & $17,51 \mathrm{aB}$ \\
& 10 & $11,27 \mathrm{cC}$ & $13,91 \mathrm{cB}$ & $18,75 \mathrm{aA}$ \\
& 30 & $13,33 \mathrm{bB}$ & $16,44 \mathrm{bA}$ & $16,07 \mathrm{aA}$ \\
& 90 & $17,62 \mathrm{~dB}$ & $9,82 \mathrm{dA}$ & $9,51 \mathrm{bA}$ \\
Kelarutan & Native & $12,47 \mathrm{aA}$ & $11,29 \mathrm{bB}$ & $6,09 \mathrm{aC}$ \\
$(\%)$ & 10 & $11,59 \mathrm{aA}$ & $8,46 \mathrm{cB}$ & $4,85 \mathrm{bC}$ \\
& 30 & $12,02 \mathrm{aA}$ & $13,71 \mathrm{aA}$ & $2,98 \mathrm{cB}$ \\
& 90 & $7,27 \mathrm{bB}$ & $11,18 \mathrm{bA}$ & $4,26 \mathrm{bC}$ \\
\hline
\end{tabular}

Secara umum pada low-medium-high amilosa pati beras terjadi penurunan swelling power dibandingkan dengan pati alaminya terkecuali pada low-amilosa dengan lama reaksi 10 menit. Hal yang serupa juga terjadi pada parameter solubility, kecuali pada medium-amilosa. Dalam pati yang dimodifikasi oleh asetilasi, introduction gugus asetil ke dalam granula pati menyebabkan pati bersifat hidrofobik yang menyebabkan air sulit masuk, sehingga mengurangi swelling power.

Jika dibandingkan dengan perbedaan kandungan amilosa, low-amilosa menunjukkan kelarutan yang sangat rendah bila dibandingkan dengan medium- dan highamilosa. Adanya introduction gugus asetil ke dalam granula pati terutama di C6 menyebabkan peningkatan berat molekul pati yang menyebabkan leaching amilosa dari granula pati menjadi semakin sulit. Karakteristik kelarutan pati asetat juga tergantung dari DS dan polimerisasi rantai amilosa dan amylopektin. [15] juga menemukan kecenderungan yang sama pada pati ubi coco terasetilasi selama 60 menit mengalami penurunan kelarutan bila dibandingkan dengan pati asli.

Selain kandungan amilosa dan lama reaksi, penggunaan metode UHP juga dilaporkan mempengaruhi sifat fisikokimia pati terasetilasi [14] seperti yang disajikan pada Tabel 7. 
Tabel 7. Rerata nilai relative crystallinity, solubility, dan swelling power pada granula pati jagung alami dan terasetilasi.

\begin{tabular}{llll}
\hline Sampel & $\mathrm{RC}(\%)^{\mathrm{b}}$ & $\mathrm{SS}_{90}(\%)^{\mathrm{c}}$ & $\mathrm{SP}_{90}(\%)^{\mathrm{c}}$ \\
\hline Native & $7,7 \pm 0,2^{\mathrm{A}}$ & $15,5 \pm 0,7^{\mathrm{F}}$ & $18,0 \pm 0,4^{\mathrm{F}}$ \\
Kontrol Reaksi & $7,6 \pm 0,2^{\mathrm{A}}$ & $37,7 \pm 0,1^{\mathrm{A}}$ & $26,2 \pm 0,9^{\mathrm{A}}$ \\
UHP1 & $7,7 \pm 0,1^{\mathrm{A}}$ & $26,7 \pm 0,5^{\mathrm{C}}$ & $21,5 \pm 0,5^{\mathrm{C}}$ \\
UHP2 & $7,6 \pm 0,5^{\mathrm{A}}$ & $23,7 \pm 1,3^{\mathrm{E}}$ & $20,1 \pm 0,7^{\mathrm{E}}$ \\
UHP3 & $7,7 \pm 0,2^{\mathrm{A}}$ & $24,8 \pm 1,0^{\mathrm{D}}$ & $20,9 \pm 0,1^{\mathrm{D}}$ \\
UHP4 & $7,8 \pm 0,1^{\mathrm{A}}$ & $27,4 \pm 0,7^{\mathrm{C}}$ & $21,4 \pm 0,3^{\mathrm{C}}$ \\
UHP5 & $7,8 \pm 0,0^{\mathrm{A}}$ & $31,1 \pm 1,3^{\mathrm{B}}$ & $22,3 \pm 0,3^{\mathrm{B}}$ \\
\hline
\end{tabular}

a nilai rata-rata dari dua pengukuran; huruf yang sama dalam kolom menunjukkan tidak berbeda secara signifikan $(\mathrm{p}<0,05)$.

b Didefinisikan sebagai persen rasio (\%) total area dari daerah puncak

kristal dengan total difraktogram (daerah kristal dan amorf).

c Kelarutan Pati (SS) dan daya kembang pati (SP) ditentukan pada suhu $90{ }^{\circ} \mathrm{C}$.

Sumber : [14]

Hasil yang berbeda dari penelitian [11] yang menunjukkan bahwa proses asetilasi dapat meningkatkan swelling power dan solubility bila dibandingkan pati alaminya (Tabel 7). Hal yang serupa juga ditunjukkan dengan adanya pemberian UHP, bahwa semakin tinggi tekanan yang diberikan maka swelling power dan solubility juga semakin tinggi. Hal ini kemungkinan besar disebabkan oleh adanya inkorporasi kelompok asetil pada molekul pati yang mencegah hubungan antar-rantai antara molekul pati asetat, dan kemudian difasilitasi oleh hidrasi sehingga menyebabkan pembengkakan granula yang dapat meningkatkan swelling granula pati terasetilasi serta meningkatkan mobilitas molekul yang mengarah ke peningkatan kelarutan pati.

Perlakuan UHP dapat menghidrasi daerah amorf dalam granula pati, sehingga menyebabkan pembengkakan granula dan distorsi daerah kristal. Dengan demikian, daerah kristalin menjadi lebih mudah diakses oleh air. UHP dapat menjadi faktor kunci untuk mempengaruhi reaktivitas granula pati dengan mempromosikan aksesibilitas reagen pada molekul granula pati.

Adanya efek yang berlawanan antara kandungan amilosa pada pati beras serta pemberian UHP pada pati jagung terhadap sweeling power dan solubility juga erat kaitannya dengan perbedaan ukuran granula pati antara jagung dan beras. Ukuran granula pati pada serealia (seperti pada beras) relatif lebih kecil dibandingkan dengan pati dari umbi-umbian (kentang) dan kacangkacangan (jagung). Ukuran granula yang semakin kecil akan menyebabkan introdution gugus asetil kedalam molekul pati akan semakin sulit, sehingga memungkinkan hal tersebut terjadi pada pati beras. Seperti yang disebutkan oleh [16] bahwa asetilasi menyebabkan peningkatan solubility pada pati kentang dan jagung.

Selain itu, granula pati beras dilaporkan lebih kaku dibandingkan pati kentang dan jagung [10]. [8] menyebutkan bahwa pati beras mempunyai perbedaan dalam kemasan intragranular dan dilaporkan bahwa rantai amilosa dikemas dalam daerah amorf serta susunan rantai amilosa dan amylopection dapat mempengaruhi reaksi substitusi kimia dalam unit glukosa makromolekul pati.

\section{c. Sifat Termal Pati Terasetilasi}

Sifat termal pati terasetilasi meliputi suhu gelatinisasi (suhu terjadinya peristiwa gelatinisasi). Suhu gelatinisasi terdiri dari suhu awal, puncak dan akhir gelatinisasi. Gelatinisasi merupakan proses pembengkakan granula pati ketika dipanaskan dalam media air. Granula pati tidak larut dalam air dingin, tetapi granula pati dapat mengembang dalam air panas. Naiknya suhu pemanasan akan meningkatkan pembengkakan granula pati. Pembengkakan granula pati menyebabkan terjadinya penekanan antara granula pati dengan lainnya. Mula-mula pembengkakan granula pati bersifat reversible (dapat kembali ke bentuk awal), tetapi ketika suhu tertentu sudah terlewati, pembengkakan granula pati menjadi irreversible (tidak dapat kembali). Kondisi pembengkakan granula pati yang bersifat irreversible ini disebut dengan gelatinisasi. Suhu gelatinisasi sangat dipengaruhi oleh lama proses asetilasi [11] dan metode penggunaan UHP [14].

Pada penelitian yang dilakukan oleh [11] yang ditunjukkan pada Tabel 8 memperlihatkan bahwa pati alami menunjukkan suhu gelatinisasi lebih tinggi bila dibandingkan dengan pati terasetilasi, selain itu semakin lama waktu proses asetilasi maka semakin rendah suhu gelatinisasi yang dibutuhkan. Tidak ada perbedaan suhu gelatinisasi dari pati alami pada berbagai kandungan amilosa. Suhu awal gelatinisasi pada high- amilosa lebih rendah dibandingkan dengan low-dan medium-amilosa, demikian juga pada parameter perubahan entalphi terendah terjadi pada high- amilosa kemudian diikuti oleh medium- dan low- amilosa. [17] menyebutkan bahwa introduksi gugus asetil ke dalam rantai polimer mengakibatkan destabilisasi struktur granular pati, sehingga lebih cepat mengalami gelatinisasi yang mengarah ke penurunan suhu gelatinisasi.

Tabel 8. Sifat termal pati beras alami dan terasetilasi yang mengandung low-medium-high- amilosa.

\begin{tabular}{|c|c|c|c|c|c|}
\hline Sampel & $\begin{array}{c}\text { Lama } \\
\text { reaksi } \\
\text { (menit) }\end{array}$ & $\mathrm{To}\left({ }^{\circ} \mathrm{C}\right)$ & $\mathrm{Tp}\left({ }^{\circ} \mathrm{C}\right)$ & $\operatorname{Tc}\left({ }^{\circ} \mathrm{C}\right)$ & $\begin{array}{c}\Delta \mathrm{H}(\mathrm{Jg} \\
1)\end{array}$ \\
\hline High- & Native & 59,79 & 65,70 & 71,05 & 7,28 \\
\hline \multirow[t]{3}{*}{ amylose } & 10 & 54,90 & 63,07 & 67,49 & 1,17 \\
\hline & 30 & 52,22 & 53,32 & 59,46 & 0,27 \\
\hline & 90 & 49,90 & 50,22 & 54,60 & 0,01 \\
\hline \multirow{4}{*}{$\begin{array}{l}\text { Meaium - } \\
\text { amylose }\end{array}$} & Native & 61,89 & 67,94 & 73,56 & 9,44 \\
\hline & 10 & 52,28 & 54,80 & 60,04 & 0,07 \\
\hline & 30 & 51,46 & 50,37 & 57,36 & 0,06 \\
\hline & 90 & 45,15 & 47,66 & 50,18 & 0,04 \\
\hline Low- & Native & 60,62 & 67,36 & 75,70 & 13,57 \\
\hline \multirow[t]{3}{*}{ amylose } & 10 & 56,57 & 61,29 & 64,30 & 0,69 \\
\hline & 30 & 50,62 & 55,99 & 65,54 & 0,42 \\
\hline & 90 & 50,17 & 57,07 & 59,68 & 0,03 \\
\hline
\end{tabular}

Sumber : [11]

Metode penggunaan UHP juga dilaporkan [14] dapat mempengaruhi suhu gelatinisasi pati jagung terasetilasi seperti yang disajikan pada Tabel 9 .

Tabel 9. Rerata suhu gelatinisasi pada pati jagung sebelum dan sesudah asetilasi

\begin{tabular}{lllll}
\hline Reaksi & $\mathrm{To}\left({ }^{\circ} \mathrm{C}\right)$ & $\mathrm{Tp}\left({ }^{\circ} \mathrm{C}\right)$ & $\mathrm{Tc}\left({ }^{\circ} \mathrm{C}\right)$ & $\Delta \mathrm{H}\left(\mathrm{Jg}^{-1}\right)$ \\
\hline Native & $64,5 \pm 0,5^{\mathrm{A}}$ & $70,7 \pm 0,1^{\mathrm{A}}$ & $87,5 \pm 0,6^{\mathrm{A}}$ & $7,6 \pm 0,2^{\mathrm{A}}$ \\
Reaksi & $56,5 \pm 0,7^{\mathrm{E}}$ & $65,0 \pm 0,7^{\mathrm{F}}$ & $85,3 \pm 0,2^{\mathrm{D}}$ & $5,3 \pm 0,4^{\mathrm{B}}$ \\
kontrol & & & & \\
UHP1 & $61,2 \pm 0,9^{\mathrm{B}}$ & $67,2 \pm 0,5^{\mathrm{B}}$ & $85,9 \pm 0,1^{\mathrm{B}}$ & $5,3 \pm 0,0^{\mathrm{B}}$ \\
UHP2 & $58,8 \pm 1,0^{\mathrm{D}}$ & $66,5 \pm 0,0^{\mathrm{D}}$ & $85,3 \pm 0,3^{\mathrm{CD}}$ & $5,1 \pm 0,0^{\mathrm{B}}$ \\
& $(63,9 \pm 0,5)^{\mathrm{C}}$ & $(69,6 \pm 0,2)$ & $(87,8 \pm 0,9)$ & $(6,6 \pm 0,8)$ \\
UHP3 & $59,7 \pm 1,0^{\mathrm{C}}$ & $67,0 \pm 0,4^{\mathrm{BC}}$ & $85,7 \pm 0,9^{\mathrm{BCD}}$ & $5,0 \pm 1,1^{\mathrm{BC}}$ \\
\hline
\end{tabular}




\begin{tabular}{lllll}
\hline & $(62,5 \pm 1,2)$ & $(69,6 \pm 0,2)$ & $(87,5 \pm 0,2)$ & $(7,1 \pm 0,2)$ \\
UHP4 & $58,9 \pm 0,5^{\mathrm{D}}$ & $66,8 \pm 0,5^{\mathrm{C}}$ & $85,7 \pm 0,8^{\mathrm{BC}}$ & $4,8 \pm 0,9^{\mathrm{C}}$ \\
& $(62,3 \pm 0,7)$ & $(69,2 \pm 0,1)$ & $(87,7 \pm 1,1)$ & $(6,8 \pm 0,3)$ \\
UHP5 & $56,6 \pm 0,8^{\mathrm{E}}$ & $66,2 \pm 0,0^{\mathrm{E}}$ & $82,2 \pm 0,9^{\mathrm{E}}$ & $4,9 \pm 0,1^{\mathrm{BC}}$ \\
& $(63,1 \pm 0,9)$ & $(68,9 \pm 0,6)$ & $(86,0 \pm 1,5)$ & $(7,6 \pm 0,3)$ \\
\hline
\end{tabular}

" Mean value of three measurements; values within a column sharing a uppercase letter are not signi ficantly different $(p<0.05)$.

belatnization onset, peak and completion temperatures are designated as $T_{\mathrm{o}}$. $T_{P_{c}}$ and $T_{c}$, respectivtly: gelatnization enthalpy is denoted as $\Delta H$.

c Values Reratarsuhusgełatinisasiopadaerpatifalamip kontrol dampdpenggunaan UHP pati jagung terasetilasi diamati menggunakan DSC. Tabel 9 menunjukkan bahwa pati alami memiliki suhu gelatinisasi baik itu suhu awal, puncak dan akhir serta entalphi yang lebih tinggi dibandingkan pati terasetilasi kontrol (metode konvensional) serta penggunaan UHP. Hal ini sesuai dengan penelitian penelitian sebelumnya yang telah dilaporkan bahwa group asetil yang tersubstitusi memecah struktur granula pati dan menghambat asosiasi rantai antar molekul pati serta memfasilitasi hidrasi granula pati $[2 ; 4 ; 8 ; 18]$. Adanya hidrasi granula pati akan mempercepat proses gelatinisasi dan membutuhkan lebih sedikit energi sehingga suhu gelatinisasi dan entalpi berkurang $[2,8]$.

\section{d. Sifat Morfologi Pati Terasetilasi}

Dari penelitian [11] yang mengamati pengaruh asetilasi terhadap morfologi granula pati beras dengan kandungan low-medium-high-amilosa selama 90 menit. Pengamatan dilakukan dengan menggunakan mikroskop elektron scanning (SEM) dan disajikan pada Gambar 2. Terlihat bahwa tidak ada efek asetilasi pada morfologi granula pati. Sodhi dan Singh (2005) juga melaporkan bahwa SEM menunjukkan tidak ada perbedaan yang signifikan antara morfologi eksternal pati alami dan asetat. Namun, peneliti melaporkan bahwa secara umum asetilasi menyebabkan agregasi granula pati. Pengamatan serupa telah dilaporkan pada morfologi pati asetat jagung dan kentang [2], serta pati beras [19]. [20] juga menunjukkan bahwa permukaan granula dari pati asetat adalah kurang halus bila dibandingkan pati alaminya. Adanya peningkatan persentase asetil menunjukkan ikatan hidrogen antar molekul terganggu dan granula pati rusak.

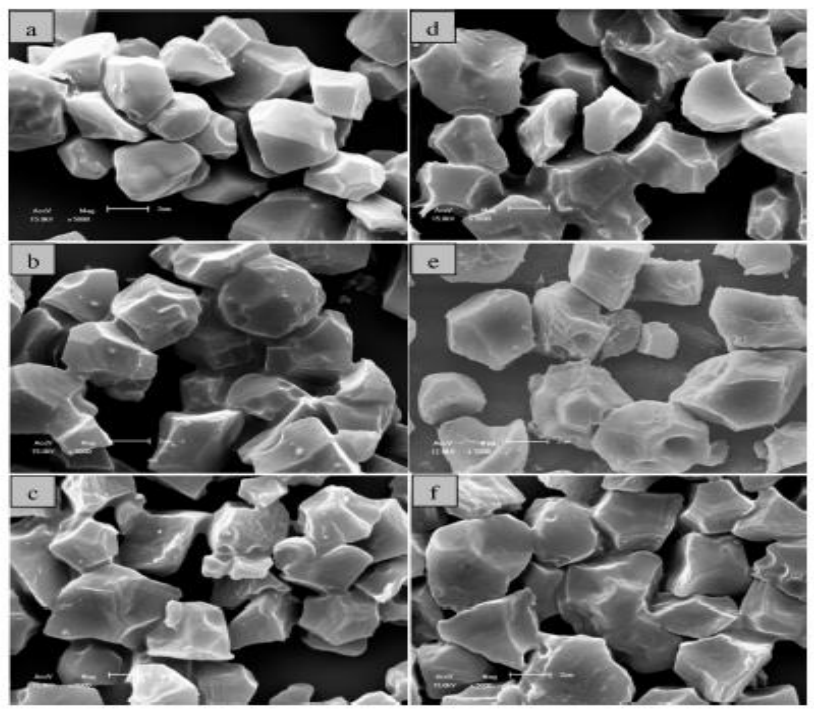

Gambar 2. SEM (Scanning Electron Micrographs) Pati beras alami high-amilosa (a), Pati beras alami medium- amilosa (b), Pati beras alami lowamilosa (c), pati terasetilasi high-amilosa (d), pati terasetilasi medium- amilosa (e ), pati terasetilasi low-amilosa (f). Angka d-f merupakan pati terasetilasi dengan lama reaksi 90 menit
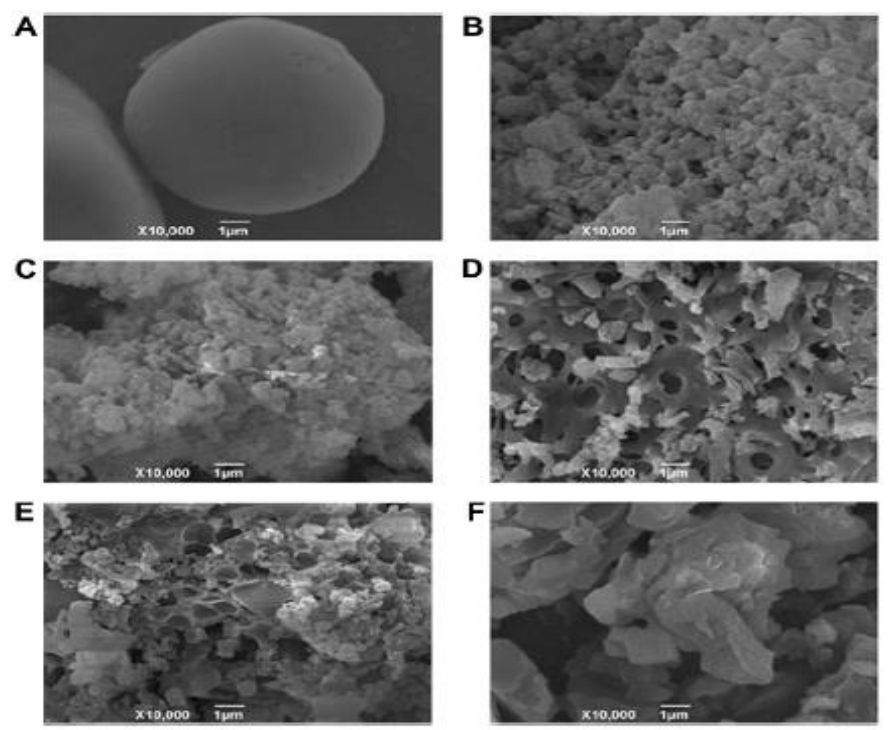

Gambar 3. Morfologi permukaan CS alami (pati jagung) dan CS asetat dengan rasio asam asetat dan asetat anhidrida yang berbeda diamati melalui SEM (10.000x): (A) CS alami; (B) CS asetat dengan rasio 2:1 (DS, 2,65); (C) CS asetat dengan rasio 1:1 (DS, 2.93); (D) CS asetat dengan rasio 1:2 (DS, 2,65); (E) CS asetat dengan rasio 01:05 (DS, 2,029); (F) CS asetat dengan rasio 00:01 (DS, 1,837).

Sifat morfologi yang diamati oleh [13] ditunjukkan pada Gambar 3 memperlihatkan bahwa adanya perbedaan antara pati jagung sebelum dan sesudah asetilasi dengan rasio asam asetat dan asetat anhidrida yang berbeda. granula pati jagung alami menunjukkan bentuk poligonal tidak beraturan dengan permukaan halus dan diameter rata-rata sekitar $10 \mu \mathrm{m}$. Morfologi ini juga telah dipaparkan oleh [21]. [22] juga menegaskan bahwa iradiasi microwave tidak memiliki efek yang signifikan terhadap morfologi dari granula pati jagung. Namun, setelah esterifikasi, struktur permukaan granul benar-benar berubah bila dibandingkan dengan pati alaminya. Terlihat bahwa morfologi awalnya halus berubah menjadi permukaan kasar yang dilapisi dengan berbagai diameter berlubang.

Adanya peningkatan DS, menyebabkan meningkatnya agregasi dan porositas pada permukaan granula pati asetat. Transformasi morfologi tersebut juga dikaitkan dengan fusi (peleburan) granula pati yang disebabkan oleh gangguan pati selama proses pemanasan. Selain itu, peneliti mengamati bahwa agregasi permukaan granula pati berkorelasi dengan rasio molar asam asetat:anhidrida asetat. Pada Gambar 3B dan D terlihat bahwa permukaan granula pati asetat dengan DS yang sama $(2,65)$ menunjukkan perbedaan struktur, pengamatan ini menguatkan fakta bahwa variasi morfologi permukaan sangat terkait dengan perubahan rasio reagen. [2] melaporkan asetilasi menyebabkan peleburan granula karena bereaksi dengan anhidrida asetat.

Selama reaksi, granula pati kehilangan integritas kemudian meleleh membentuk struktur baru [23]. Peleburan ini terutama akibat dari introduksi gugus asetil menyebabkan terganggunya dan melemahnya struktur internal granula. Asetilasi pati terjadi di wilayah amorf dari 
granula yang terdiri dari amilosa. Namun, selama asetilasi, granul menjadi lebih berpori, membuat granula pati asetat berubah menjadi fragmen kecil [24]. Dengan demikian hasil SEM menunjukkan bahwa terjadi erosi yang kuat pada morfologi pati jagung alami setelah esterifikasi, perubahan ini terkait dengan variasi rasio asam asetat dan asetat anhidrida.

\section{e. Sifat Pasting Pati Terasetilasi}

Ciri fisik pasta pati terutama didasarkan pada pola pembentukan pasta dan profil perubahan viskositas selama pemanasan. Penelitian yang dilakukan oleh [11] yang mengamati pengaruh asetilasi terhadap morfologi granula pati beras dengan kandungan low-medium-highamilosa ditunjukkan pada Tabel 10 .

Tabel 10. Sifat pasting pati beras alami dan terasetilasi yang mengandung low-medium-high-amilosa.

\begin{tabular}{|c|c|c|c|c|}
\hline Sifat & $\begin{array}{l}\text { Lama } \\
\text { reaksi }\end{array}$ & $\begin{array}{l}\text { High- } \\
\text { amylose }\end{array}$ & $\begin{array}{l}\text { Medium- } \\
\text { amylose }\end{array}$ & $\begin{array}{l}\text { Low- } \\
\text { amylose }\end{array}$ \\
\hline Pasting & Native & $75,42 \mathrm{bA}$ & $70,65 \mathrm{aB}$ & $65,85 \mathrm{aC}$ \\
\hline temperature & 10 (menit) & $81,80 \mathrm{aA}$ & $62,55 \mathrm{bB}$ & $50,22 \mathrm{bC}$ \\
\hline \multirow[t]{2}{*}{$\left({ }^{\circ} \mathrm{C}\right)$} & 30 (menit) & $61,97 \mathrm{cA}$ & $59,55 \mathrm{bcA}$ & $50,07 \mathrm{bB}$ \\
\hline & 90 (menit) & nd & $52,77 \mathrm{cA}$ & $53,35 \mathrm{bA}$ \\
\hline Peak & Native & $261,66 \mathrm{bC}$ & $290,50 \mathrm{aB}$ & $324,37 \mathrm{bA}$ \\
\hline viscosity & 10 (menit) & $318,00 \mathrm{aB}$ & $204,29 b C$ & $413,37 \mathrm{aA}$ \\
\hline \multirow[t]{2}{*}{$(R V U)$} & 30 (menit) & $285,54 b B$ & $203,54 b C$ & $393,62 \mathrm{aA}$ \\
\hline & 90 (menit) & $47,33 \mathrm{cB}$ & $131,41 \mathrm{cA}$ & $107,83 \mathrm{cA}$ \\
\hline Breakdown & Native & $30,46 \mathrm{bcA}$ & $51,08 \mathrm{aA}$ & $178,25 \mathrm{bB}$ \\
\hline \multirow[t]{3}{*}{$(R V U)$} & 10 (menit) & $65,87 \mathrm{aB}$ & $23,96 b C$ & $284,62 \mathrm{aA}$ \\
\hline & 30 (menit) & $36,83 \mathrm{abB}$ & $25,12 \mathrm{bB}$ & $280,92 \mathrm{aA}$ \\
\hline & 90 (menit) & $4,38 \mathrm{cB}$ & $1,50 \mathrm{cB}$ & $80,71 \mathrm{cA}$ \\
\hline Final & Native & $349,54 \mathrm{aA}$ & $347,21 \mathrm{aA}$ & $197,08 \mathrm{bB}$ \\
\hline viscosity & 10 (menit) & $325,21 \mathrm{abA}$ & $284,87 \mathrm{bB}$ & $318,37 \mathrm{aA}$ \\
\hline \multirow[t]{2}{*}{$(R V U)$} & 30 (menit) & $312,42 \mathrm{bAB}$ & $290,00 \mathrm{bB}$ & $321,42 \mathrm{aA}$ \\
\hline & 90 (menit) & $104,12 \mathrm{cB}$ & $223,62 \mathrm{cA}$ & $55,58 c \mathrm{C}$ \\
\hline Setback & Native & $118,33 \mathrm{aA}$ & $107,79 \mathrm{aA}$ & $50,96 \mathrm{bB}$ \\
\hline \multirow[t]{3}{*}{$(R V U)$} & 10 (menit) & $73,08 \mathrm{bC}$ & $104,54 \mathrm{aB}$ & $189,62 \mathrm{aA}$ \\
\hline & 30 (menit) & $63,71 b C$ & $111,58 \mathrm{aB}$ & $208,71 \mathrm{aA}$ \\
\hline & 90 (menit) & $61,16 \mathrm{bB}$ & $93,71 \mathrm{aA}$ & $28,46 \mathrm{cC}$ \\
\hline
\end{tabular}

Dari Tabel 10. Secara umum terlihat bahwa terjadi penurunan suhu pembentukan pasta pada pati beras terasetilasi dengan kandungan low-medium-high-amilosa pada berbagai lama reaksi bila dibandingkan dengan pati alaminya kecuali pada high-amilosa 10 menit dengan nilai DS terendah. Karakteristik ini menjadi salah satu dari banyak keuntungan yang diperoleh dari proses asetilasi, karena memungkinkan penggunaan pati asetat sebagai "thickening agent" dimana pati harus tergelatinisasi pada suhu yang lebih rendah, sehingga dapat mengurangi biaya energi selama pembuatan produk di mana pati ini digunakan [25]. Menurut [26] penurunan suhu pembentukan pasta berkaitan erat dengan penurunan suhu gelatinisasi karena adanya pengurangan interaksi rantai pati yang akan mengurangi keperluan energi untuk hidrasi dan disrupsi struktur pati.

Pati beras high-amilosa terasetatilasi selama 10 menit dan pati beras low-amilosa terasetatilasi selama 10 dan 30 menit memiliki viskositas puncak yang lebih tinggi daripada pati alaminya. Ketika lama reaksi 90 menit untuk pati beras high dan low- amilosa, viskositas puncak menurun dibandingkan dengan pati alaminya. Viskositas puncak pati beras medium-amilosa lebih rendah daripada pati alaminya. Asetilasi mengurangi viskositas akhir pati beras terasetilasi dibandingkan dengan pati alaminya, kecuali untuk pati beras high-amilosa selama 10 menit dan pati beras low- amilosa selama 10 dan 30 menit. [27] menemukan bahwa viskositas pati ganyong terasetilasi lebih rendah dibandingkan pati alaminya.

Penurunan viskositas pati asetat dibandingkan dengan pati alaminya dapat dikaitkan dengan masuknya kelompok asetil yang menghambat hubungan antara rantai molekul pati dan penurunan kemampuan granula pati untuk menyerap air. Dengan demikian, memberikan pati berkarakter hidrofobik. Selain itu metode penggunaan UHP yang disampaikan oleh [14] bahwa UHP memfasilitasi penetrasi anhidrida asetat untuk introduce ke dalam granula interior/matriks pati sehingga memudahkan air masuk dan mengurangi viskositas granula pati seperti yang disajikan pada Tabel 11.

Tabel 11. Karakteristik Viskositas Pasting pada granula pati jagung alami dan terasetilasi

\begin{tabular}{|c|c|c|c|c|c|}
\hline Reaksi & Peak (RVU) & $\begin{array}{l}\text { Trough } \\
(R V U)\end{array}$ & Final (RVU) & $\begin{array}{l}\text { Breakdow } \\
n(R V U)\end{array}$ & $\begin{array}{l}\text { Setback } \\
(R V U)\end{array}$ \\
\hline Native & $262,3 \pm 2,1^{A}$ & $180,7 \pm 4,0^{\mathrm{A}}$ & $274,0 \pm 4,0^{\mathrm{F}}$ & $81,7 \pm 5,7^{\mathrm{B}}$ & $93,3 \pm 7,8^{c}$ \\
\hline $\begin{array}{l}\text { Kontrol } \\
\text { reaksi }\end{array}$ & $259,7 \pm 3,8^{\mathrm{B}}$ & $128,3 \pm 1,5^{F}$ & $313,3 \pm 3,8^{A}$ & $\begin{array}{l}131,3 \pm 2, \\
3^{\mathrm{A}}\end{array}$ & $\begin{array}{l}185,0 \pm 2 \\
6^{\mathrm{A}}\end{array}$ \\
\hline UHP1 & $208,3 \pm 2,3^{D}$ & $132,3 \pm 3,8^{\mathrm{D}}$ & $289,0 \pm 3,6^{c}$ & $76,0 \pm 3,0^{\mathrm{D}}$ & $\begin{array}{l}156,7 \pm 0 \\
6^{C}\end{array}$ \\
\hline UHP2 & $\begin{array}{l}185,3 \pm 1,5^{\mathrm{F}} \\
(262,7 \pm 3,2)^{\mathrm{b}}\end{array}$ & $\begin{array}{l}120,7 \pm 1,5^{c} \\
(177,3 \pm 4,7 \\
)\end{array}$ & $\begin{array}{l}257,0 \pm 1,0^{C} \\
(276,7 \pm 2,9)\end{array}$ & $\begin{array}{l}64,7 \pm 1,5^{F} \\
(85,3 \pm 7,5 \\
)\end{array}$ & $\begin{array}{l}136,3 \pm 0, \\
6^{\mathrm{F}} \\
(99,3 \pm 4,7 \\
)\end{array}$ \\
\hline UHP3 & $\begin{array}{l}221,0 \pm 3,0^{\mathrm{C}} \\
(268,0 \pm 6,1)\end{array}$ & $\begin{array}{l}142,0 \pm 3,5^{B} \\
(181,7 \pm 9,0\end{array}$ & $\begin{array}{l}311,0 \pm 3,6^{\mathrm{B}} \\
(285,3 \pm 6,1)\end{array}$ & $\begin{array}{l}79,0 \pm 1,7 \mathrm{C} \\
(86,3 \pm 3,1 \\
)\end{array}$ & $\begin{array}{l}169,0 \pm 2, \\
6^{\mathrm{B}} \\
103,7 \pm 4 \\
0\end{array}$ \\
\hline UHP4 & $\begin{array}{l}207,7 \pm 3,2^{\mathrm{D}} \\
(277,7 \pm 4,5)\end{array}$ & $\begin{array}{l}135,7 \pm 1,5 c \\
(200,0 \pm 17, \\
8)\end{array}$ & $\begin{array}{l}285,3 \pm 1,5^{D} \\
(284,7 \pm 2,3)\end{array}$ & $\begin{array}{l}72,0 \pm 1,7 \mathrm{E} \\
(77,7 \pm 13 \\
7)\end{array}$ & $\begin{array}{l}149,7 \pm 2, \\
3^{\mathrm{E}} \\
(84,7 \pm 20 \\
0)\end{array}$ \\
\hline \multicolumn{6}{|c|}{ 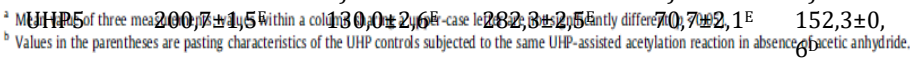 } \\
\hline & $(282 \pm 3,2)$ & $(185,7 \pm 5,5$ & $(292,0 \pm 2,0)$ & )$^{(96,7 \pm 2,3}$ & $\begin{array}{l}(106,3 \pm 3, \\
8)\end{array}$ \\
\hline
\end{tabular}

\section{Aplikasi Pati Terasetilasi pada Pembentukan Film}

Saat ini pati termodifikasi sangat banyak digunakan untuk berbagai tujuan pembuatan produk yang menggunakan pati sebagai bahan baku utama ataupun sebagai bahan baku sekundernya. Sesuai dengan tujuan awal modifikasi pati dilakukan untuk mengurangi kelemahan dari sifat alami pati antara lain tidak tahan terhadap panas, kondisi asam ataupun untuk menghambat laju retrogradasi pati. Proses asetilasi dapat meningkatkan kestabilan pasta dan kejernihan, serta dapat mencegah retrogadasi. Tingkat asetilasi juga dapat dibatasi sehingga dapat memperbaiki sifat-sifat yang diperlukan.

Dalam aplikasinya berdasarkan tingkat derajat substitusi, pati asetat diklasifikasikan menjadi tiga tingkat yakni rendah, menengah, tinggi. Pati asetat dengan DS rendah $(0,01-0,2)$ dapat berfungsi sebagai pembentuk film, pengikat, pelekat, penebal, penstabil, dan agen texturing, dan beberapa digunakan dalam berbagai macam makanan termasuk makanan yang dipanggang, pengisi pie kaleng, saus, sup, makanan beku, makanan bayi, salad dressing, dan makanan ringan. Pati asetat dengan DS menengah $(0,2-$ $1,5)$ dan DS tinggi $(1,5-3)$ serta memiliki kelarutan yang tinggi didalam aseton dan kloroform dapat digunakan sebagai bahan thermoplastic [12].

Seiring dalam menanggapi tren pemasaran kearah bahan yang lebih ramah lingkungan, pati telah menerima banyak perhatian untuk dijadikan sebagai film biopolimer sebagai pengganti film sintetis dalam aplikasinya sebagai bahan pengemas makanan karena sifatnya biodegradable 
dan biaya rendah [26]. Untuk itu, pada penelitian yang dilakukan oleh [28] yang meneliti tentang kemampuan pembentukan film pada pati jagung yang dimodifikasi secara kimia. Pada tahap penelitian pemilihan jenis dan konsentrasi pati yang dimodifikasi untuk membentuk film terlihat bahwa pati terasetilasi memiliki shear stress yang paling tinggi bila dibandingkan dengan modifikasi kimia pati yang lain seperti terlihat pada Gambar 4 .
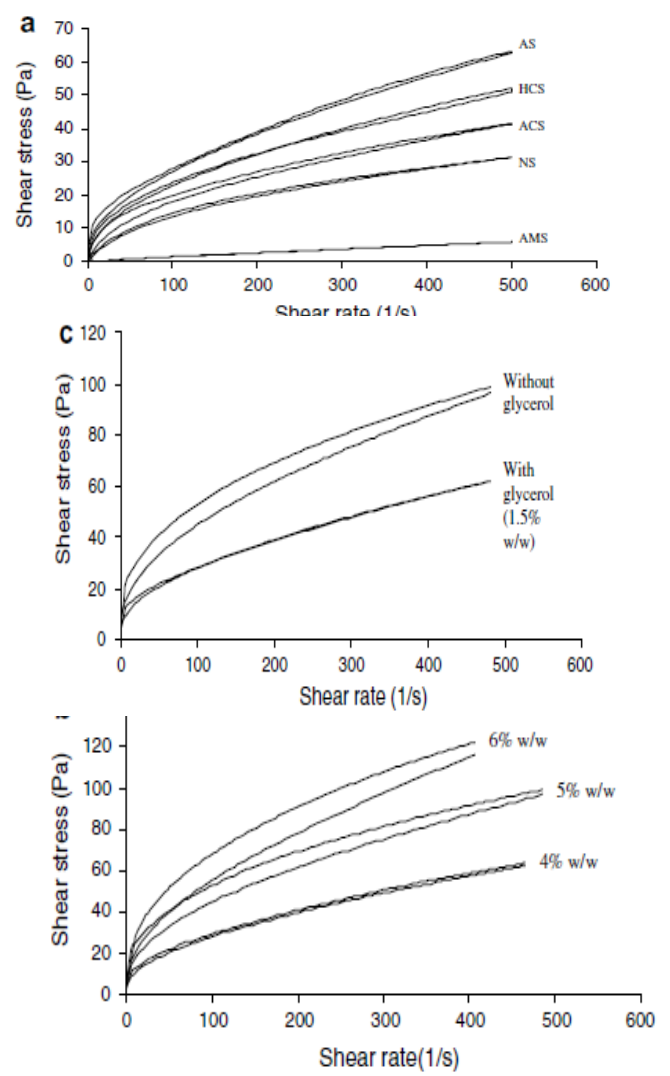

Gambar 4. Perilaku rheologi berbagai suspensi filmogenic (a) 4\% b/b suspensi filmogenic dari: pati asetat (AS), pati asetat cross-linked (ACS), pati hydroxypropylated cross-linked (HCS), acid modification starch (AMS) dan pati alami (NS). (b) suspensi Filmogenic dari 4\%, 5\% dan 6\% b/b AS. (c) suspensi Filmogenic dari 5\% b/b AS tanpa gliserol dan dengan gliserol pada konsentrasi 1,5 g/100 g suspensi filmogenic.

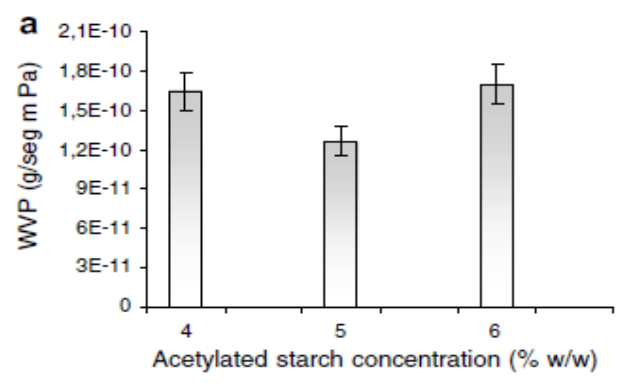

Gambar 5. Pengaruh konsentrasi pati jagung asetat pada permeabilitas uap air (WVP) film

Pada Gambar 4. semua suspensi filmogenic dari modifikasi kimia pati diuji kemampuannya membentuk film. Dari semua pati yang yang dimodifikasi secara kimia, pati asetat menunjukkan karakteristik terbaik untuk membentuk film karena nilai shear stress yang dihasilkan lebih tinggi bila dibandingkan pati dengan modifikasi kimia yang lain, selain itu lebih transparan. Kemampuan pembentukan film terkait dengan amilosa terutama ukuran rantai amilosa dan amilopektin [29]. Jadi, meskipun pati asetat mempunyai kandungan amilosa rendah tetapi mungkin derajat polimerisasi rantai amilosanya yang tinggi.

Suspensi Filmogenic dari pati asetat menggunakan konsentrasi berkisar antara $4 \%$ dan $6 \%$ b/b terbentuk film dengan penampilan yang baik. Karena, WVP adalah sifat penting dalam film yang dikembangkan dari bahan hidrofilik untuk digunakan dalam memilih konsentrasi pati asetat optimum. Maka diperoleh konsentrasi pati $5 \%$ b/b sebagai konsentrasi optimum karena memiliki nilai WVP terendah yakni $1.26 \times 10^{-10} \mathrm{~g} / \mathrm{s}$ $\mathrm{mPa}$ (Gambar 5).

\section{Kesimpulan}

a. Pada pati beras, semakin tinggi kandungan amilosa pati maka \% derajat substitusi dan \% asetil menurun, begitu pula sebaliknya.

b. Semakin lama waktu reaksi pati maka \% derajat Substitusi dan \% asetil meningkat, serta Swelling Power dan Solubility nya semakin tinggi akan tetapi juga dipengaruhi oleh ukuran granula pati

c. Adanya penambahan katalisator dan pre treatment penambahan asam asetat akan meningkatkan derajat substitusi pati terasetilasi dibandingkan dengan pati alami

d. Perlakuan UHP mempengaruhi proses asetilasi yang dapat mengurangi suhu dan lama proses, serta menurunkan temperatur gelatinisasi dan sifat pasta

e. Sifat morfologi pati terasetilasi lebih poros, kurang halus dan sedikit remah dibandingkan dengan pati alami

f. Tidak ada perbedaan signifikan pada kandungan amilosa beras terhadap sifat pasting dan viskositas akan tetapi semakin lama waktu reaksi maka sifat pasting dan viskositas pati beras terasetilasi semakin menurun

g. Pati jagung terasetilasi berpotensi dijadikan sebagai bahan pembentuk film.

\section{DAFTAR RUJUKAN}

[1] Xu, Y., Miladinov, V., \& Hanna, M. A. "Synthesis and characterization of starchacetates with high substitution". Cereal Chemistry, 81, 735-740. 2004.

[2] Singh, N., Chawla, D., \& Singh, J. "Influence of acetic anhydride on physico-chemical, morphological and thermal properties of corn and potato starch". Food Chemistry, 86, 601-608. 2004.

[3] Smith, Michael B., "Organic Chemistry: An acid-base approach" Taylor and FrancisGroup, USA. 2011.

Huang, J., Schols, H., Jin, Z., Sulmann, E., \& Voragen, A. G. J. "Pasting proper-ties and (chemical) fine structure of acetylated yellow pea starch is affected byacetylation reagent type and granule size". Carbohydrate Polymers, 68, 397-406. 2007.

[5] Huber, K. C., \& BeMiller, J. N. "Channels of maize and sorghum starch granules". Carbohydrate Polymers, 41, 269-276. 2000

[6] Bertolini, A.C., Starches Characterization, Properties, and Applications. CRC Press Taylor and Francis group. USA. 2010. 
[7] Li, W., Xiao, X., Zhang W., Zheng, J., Ouyang, S., Zhang,G., Luo, Q." Compositional, morphological, structural and physicochemical properties of starches from seven naked barley cultivars grown in China". Food Research International, 58, 7-14. 2010

[8] Sodhi, N. S., \& Singh, N. "Characteristics of acetylated starches preparedusing starches from different rice cultivars". Journal of Food Engineering, 70,117-127. 2005

[9] Islam, M. N., Rutledge, J. E., \& James, W. H. "Influence of rice crystallinity on cross-linking". Cereal Chemistry, 51, 51-56. 1974

[10] Singh, N., Singh, J., Kaur, L., Sodhi, N. S., \& Gill, B. S. "Morphological, thermal and rheological properties of starches from different botanical sources-a review". Food Chemistry, 81, 219-231. 2003.

[11] Colussi,R, Pinto, V.Z, Halal, S.L.M.E, Vanier, N.L., Villanova, F. A., Silva, R.M., Zavareze, E.S, Dias, A.R.G. "Structural, morphological, and physicochemical properties ofacetylated high-, medium-, and lowamylose rice starches". Carbohydrate Polymer 103, 405413. 2014

[12] Luo, Z.-G., \& Shi, Y.-C. "Preparation of acetylated waxy, normal, and high-amylose maize starches with intermediate degrees of substitution in aqueoussolution and their properties". Journal of Agricultural and Food Chemistry, 60, 9468-9475. 2012

[13] Diop, C., Li, H. L., Xie, B. J., \& Shi, J. "Effects of acetic acid/acetic anhydride ratioson the properties of corn starch acetates". Food Chemistry, 126, 1662-1669. 2011

[14] Choi, YS., Kim H-S., Park, C-S., Kim, B-Y., Baik, M-Y. "Ultra high pressure (UHP)-assisted acetylation of corn starch". Carbohydrate Polymers, 78, 862-868. 2009

[15] Lawal, 0. S. "Composition, physicochemical properties and retrogradationcharacteristics of native, oxidised, acetylated and acid-thinned new cocoyam (Xanthosoma sagittifolium) starch". Food Chemistry, 87, 205-218. 2004.

[16] Mbougueng, P. D., Tenin, D., Scher, J., \& Tchiégang, C. "Influence of acetylationon physicochemical, functional and thermal properties of potato and cassava starches". Journal of Food Engineering, 108, 320-326. 2012

[17] Wotton, M., \& Bamunuarachchi, A. "Application of DSC to starch gelatiniza-tion". Starch/Stärke, 31, 201-204 1979.

[18] Wang, L., \& Wang, Y. J. "Rice starch isolation by neutral protease and high-intensity ultrasound". Journal of Cereal Science, 39, 291-296. 2004

[19] Gonzalez, Z., \& Perez, E. "Effect of acetylation on some properties of rice starch". Starch/Stärke, 54, 148-154. 2002.

[20] Sha, X. S., Xiang, Z. J., Bin, L., Jing, L., Bin, Z., Jiao, Y. J., et al. "Preparation andphysical characteristics of resistant starch (type 4) in acetylated indica rice". Food Chemistry, 134, 149-154. 2012

[21] Chung, Y. L., \& Lai, H. M. "Molecular and granular characteristics of corn starch modified by HCl-methanol at different temperatures". Carbohydrate Polymers, 63, 527-534. 2006.

[22] Jie, M. G., Peng, W., Sheng, M. X., Xing, Z., \& Tong, Z. "Crosslinking of corn starch with sodium trimetaphosphate in solid state by microwave irradiation". Journal of Applied Polymer Science, 102, 5854-5860. 2006

[23] Yan, H., \& Zhengbiao, G. U. "Morphology of modified starches prepared by different methods". Food Research International, 43(20), 767-772. 2010.

[24] Wang, X., Gao, W. Y., Zhang, L. M., Xiao, P. G., Yao, L. P., Liu, Y. "Study on the morphology, crystalline structure and thermal properties of yam starch acetates with different degrees of substitution". Science in China Series BChemistry, 51(9), 859-865. 2008.

[25] Betancur, A. D., Chel, G. L., \& Canizares, H. E. "Acetylation and characteriza-tion of Canavalia ensiformis starch". Journal of Agricultural and Food Chemistry, 45,378-382. 1997.

[26] Liu, Z. "Edible films and coatings from starches". In J. H. Han (Ed.), Innovations in food packagings (pp. 318336). Amsterdam, The Netherlands: Elsevier. 2005.

[27] Saartrat, S., Puttanlek, C., Rungsardthong, V., \& Uttapap D. "Paste and gel properties of low-substituted acetylated canna starches". Carbohydrate Polymers, 61, 211-221. (2005).

[28] López, O., García, M., Zaritzky, N. “Film forming capacity of chemically modified corn starches". Carbohydrate. Polymers. 73, 573-581. 2008.

[29] Mali, S., Sakanaka, L., Yamashita, F., Grossmann Eiras, M. "Water sorption and mechanical properties of cassava starch films and their relation to plasticizing effect". Carbohydrate Polymer. 60, 283-289. 2005. 